\title{
Exploring Foreign Direct Investments in Developing African Countries: Their Effects on the Economic Growth in Cameroon (2006-2011)
}

\author{
Efiong Akwaowo \\ College of Business and Professional Studies, Ashford University, Denver, USA. \\ Email: efieson@yahoo.com
}

Received January $19^{\text {th }}, 2013$; revised February $28^{\text {th }}, 2013$; accepted March $10^{\text {th }}, 2013$

\begin{abstract}
This study explores Foreign Direct Investment (FDI) and its effects on the economic growth in Cameroon within the period 2006-2011. The purpose of this study is to understand the reason why increased FDI had not led to more economic growth in Cameroon. Aghion's endogeneity growth theory was used as a guide to data collection and analysis. Research data were collected from 20 investment managers with close relationships with Cameroon. The participants included five from each subgroup of energy, health care, technology, and financial institutions, in the United States. The study participants expressed strong commitment towards economic growth in Cameroon. The responses from the study participants showed inconsistency with the literature review and the belief that FDI generates economic growth in the developing countries. Moreover, the respondents reported bureaucracy and corruption as the possible challenges facing the economic growth in Cameroon. The research participants believed that eco-political factors directly affect the economic growth in Cameroon. Policy implications and recommendations for future studies were stated. It was recommended that the country must improve its financial market by removing financial restraints that hinder Cameroon firms from getting into export markets. In addition, the Cameroon leaders should focus on improving human capital through training and development. Training methods must be improved; a comprehensive plan for training and development must be implemented. Moreover, Cameroon leaders should ensure that their attention to FDI does not overshadow domestic small businesses. The study established that although there were positive relationships between FDI and economic growth in the developing countries such as Cameroon, the findings were inconclusive. Future research should further study the effects of FDI on economic growth using endogeneity growth theory in multi developing countries to determine if the study findings from this dissertation can be supported in other settings.
\end{abstract}

Keywords: Foreign Direct Investments (FDI); Economic Growth; Economic Development; Developing Countries

\section{Introduction}

Cameroon is a country located in the central West Africa. Based on 2011 estimate, the country has a population of about 19,711,291 [1]. Cameroon has generally been a stable country. This stability has encouraged more inflow of FDI into the country to explore its rich natural resources. Cameroon's political power remains mostly in the hands of President Paul Biya who has been in power for over 30 years. Like many Sub-Saharan African countries, Cameroon is faced with many political and economic problems such as, corruption, poor technological advancement, high unemployment, and a generally poor standard of living. The country has been successful in improving economic laws, policies and, other legal instruments in order to attract more foreign investments, which many economists believe is the key to facilitating economic growth in the host country [2]. However, the recent increase in FDI inflow into Cameroon has not resulted in a better and sustained economic growth as had been expected. Cameroon's population is about 18,175,000 [3]. The country is currently experiencing an unemployment rate of about 30\% [4]. In January, 1960 the area formerly ruled by France won its independence. In October 1961, the territory formerly ruled by the British also gained its independence. According to the Cameroon Embassy in the Netherland (2009):

Following agitation for independence by the Southern Cameroons - before the name was changed to West Cameroon-a plebiscite was held in that sector of Cameroon on February 11th 1961 under the United Nations supervision. The result of the plebiscite which was overwhelming for reunification $(233,571$ against 97,741) gave Southern Cameroons automatic independence and unification, which was achieved on October 1st 1961 (p. 2). 
After the reunification of both sectors, the Federal Republic of Cameroon was created. Before mid 1980, Cameroon leaders adopted a policy that the public sector rather than private enterprises played a vital role in the economic development of Cameroon [5]. Government reforms from the 1980s have shown progress toward trade liberalization, foreign investments and privatization. Many classical economists such as [6,7] based their forecasts of growth on the assumption that most developing countries are naturally rich. Forgha had argued that these countries are rich with natural resources which when refined, could serve as engines of growth and development. However, Forgha explained that because of their low income but high desire to consume, the citizens of these developing countries tend to have a low saving rate. The low savings rate leads to the low rates of capital formation that are associated with high rates of poverty. Forgha and some classical economists such as [8] argued that developing countries must encourage the inflow of FDI. Forgha asserted that the inflow of more FDI into these developing countries would serve as "complement to domestic investment so as to provide these developing countries with their desired economic growth and development" (p. 56).

\section{Background}

In the 1960s, there was a wave of political independence in most of the African countries. This led to some skepticism among the leaders for fears that economic development could lead to the loss of their political sovereignty and environmental pollution (Njong, 2008). However, according to Njong, the disappointing economic downturn in African countries from the early 1970s to the 1990s and other world economic activities led to the need for more FDI into the region. In this study, the principles of good governance were examined in the light of the contribution that they offer to foreign investors. Before Cameroon won its independence, the country's government attempted to encourage foreign capital inflow into the economy. Over the years, the government enacted a series of legal instruments to encourage and boost FDI inflow at the national level in order to foster the economic growth. Such instruments included the Investment Code of 1990, amended in 1994; the Patent Rights Act, also called the Bangui Agreement, initially enacted in March 1977 and amended in February 1999; the Paris Convention for the Protection of and promotion of Industrial Property of 1883, revised in 1990; and bilateral investment treaties for the protection and promotion of investments signed in 1966 (Forgha, 2009). The enactment of these decrees, laws, and policies, increased the annual average of FDI inflow in dollars, but has not generated a sustained economic growth in the country. This has resulted in high unemployment, low technological advancement and poor standard of living [9]. The reasons for Cameroon's poor economic growth despite the increase in FDI dollars have not fully been identified and addressed.

By 2009, many foreign and multinational enterprises (MNEs) had established operations in Cameroon, and many foreign banks and private investors had invested in the form of loans. As MNEs transferred management and technology know-how to the domestic firms, it was expected that their presence would improve the economic growth of Cameroon, the host country [10]. Cameroon leaders welcomed the increased FDI and foreign operations into the nation. This was based on their belief, shared with the leaders of many developing countries that FDI generate economic growth in a country. The leaders believed that FDI would bring structural technological transformation, which cannot be afforded by the domestic authorities. However, despite the overall increase in FDI inflow into Cameroon from 1986 to 1993 , the real growth of GDP per capita remained at $-6.14 \%$ on average (Forgha, 2009).

Some progress appeared to have been made when the average annual FDI inflow into Cameroon increased from \$284 million and \$270 million in 2007 and 2008 respectively, to $\$ 337$ million in 2009 , primarily because of higher oil prices (United Nation Council on Trade and Development [11]. Nevertheless, (UNCTAD, 2010) reported that Cameroon's GDP growth was $-1.5 \%$ in 2009. Cameroon has experienced less GDP than comparable Sub-Saharan countries, such as Nigeria, Ghana, and Liberia, which had experienced GDP growth of $2.9 \%, 3.5 \%$, and $4.6 \%$ respectively, in 2009 [12]. Similarly [13] indicated that FDI inflow into the country has not resulted in higher rates of economic growth and technological development.

The dismal economic progress is puzzling because, as a bilingual country, Cameroon has an advantage in attracting FDI from both French and English-speaking developed countries (Forgha, 2009). In recent years, it has been able to attract more FDI due to much-improved governance, economic policies, and other legal instruments. However, the increased FDI has not generated more economic growth as anticipated. The reasons for Cameroon's low economic growth despite the increased FDI have not fully been identified and addressed (Njong, 2008). To address this research gap, this qualitative study explored the effects of FDI on Cameroon economy in terms of responsibilities, challenges, trends, and governance focusing on the period between 2006 and 2009. The principle of endogeneity growth theory literature was applied to establish the theoretical framework of this research [14]. The review was explored and explained the need to associate Cameroon's economic growth with endogeneity theory. 


\section{Theoretical Framework}

Aghion and Howitt (1987) introduced an approach to understanding how FDI can generate economic growth in a country. This approach was called the endogeneity growth theory [15]. The purpose of endogeneity growth theory was to seek some understanding of the interplay between technological knowledge and various structural "characteristics of the economy and the society, and how such interplay results in economic growth" [16]. Scholars are increasingly recognizing FDI as an engine of economic growth mostly in the developing countries [17]. Many scholars such as [18] asserted that FDI is a major source of economic growth in developing countries. Wanted to show that endogenous growth theory provides a strong and flexible tool of analysis that can be used to research not only economic growth but also many other related phenomena [19].

The theoretical framework of this study was based on the premise that FDI generate and facilitate economic growth in Cameroon through producing positive spillover effects on the economy (Eden, 2008; Wijeweera \& Dollery, 2010). There is an important fact about FDI and economic growth in the endogeneity growth theory, which FDI is theorized to have positive effect on economic growth through knowledge and technological spillovers. Focusing on the creation of technological knowledge transmission, endogeneity growth theory posits that the incentives that drive invention and creation are the main components of economic growth. According to the theory, knowledge and technology are characterized by more returns that propel economic growth (Ahmed, 2008). The endogeneity growth theory suggests that research and development activities are purposeful investments in new knowledge, which is itself an input in the process of generating economic growth in the host country (Acs, Braunerhjelm, \& Carlson, 2009). Thus, local firms that gain access to talent and technological know-how from increased FDI are able to innovate and create new industries, thereby increasing economic growth [20]. Such positive spillover strengthening the host country's economy [21] is particularly significant when highly advanced MNEs enter a developing market, such as Cameroon, where the technological gap is wide.

The major reason for examining FDI spillovers from MNEs to the host country was to understand how FDI contribute to the economic growth of the host country (Ofori-Brobbey, Ojode, \&Woldie (2010). In a cross country regression framework [22] studied the effect of FDI on economic growth. It was found that FDI was an important mechanism for the transfer of technology and contributing more to the economic growth than domestic investment. In addition, [23] found from their research that FDI have a significant, positive role on the economic growth of developing countries through knowledge spillovers.

Scholars are increasingly recognizing FDI as an engine of economic growth mostly in developing countries. However, researchers have conducted very little studies regarding the reason why increased FDI failed to generate more economic growth in Cameroon [24]. FDI play a very important role in the developing countries [25]. FDI can affect output and income by increasing the stock of capital, increase labor force through job creation, and enhance human capital through technology [26]. Hoang et al. (2010) examined the effects of FDI on economic growth in Vietnam, using the panel data model across 61 provinces in 1995 through 2006. The studies showed a positive growth and trade in Vietnam. However, empirical studies indicated that the effect of FDI on economic growth has been far from conclusive. A number of applied papers have looked at the FDI nexus such as [27]. The studies do not tend to support the view that FDI generate economic growth.

There was another study by [28] on the role of FDI in high medium, low medium and low income countries during 1970-2006. The studies did not tend to support the view that FDI generate economic growth. The researchers used the World Bank's four-fold classification. The study examined whether FDI inflows complement domestic investment of the recipient country, and contribute to the host country economic growth. The test rejected the hypothesis of FDI-led growth in these countries. The study casted some doubts on the validity of many developing countries encouraging FDI inflows, with the belief that FDI inflows would lead to higher economic growth. Nevertheless, the endogenous growth model contends that FDI contribute to domestic growth of the host country by complementing investment.

\section{The Literature Review}

The intent of this study was to explore the reasons why the increased FDI into Cameroon failed to result in more economic growth; despite the assertion by many leading economists such as (Ofori-Brobbey, Ojode, \& Woldie, 2010). The purpose of this qualitative case study was to understand the reasons why increased FDI did not lead to a more economic growth in Cameroon. Forgha (2009) noted that prior to 1966; many developing countries depended on foreign financial assistance for economic survival. To develop economic growth, Cameroon and other developing countries, have to make progress on some areas such as technology, education and infrastructure [29].

Since FDI was expected to be a major source of economic growth in developing countries such as Cameroon, the literature review mostly was involved in the exploration of the effects of FDI in the economic growth of 
Cameroon through spillovers. A great number of peerreview publications and other suitable sources justified the worthiness of the study, based on the literature review. To ensure the relevance of the materials, only sources published between 2006 and 2010 were reviewed. Earlier sources were reviewed only if new materials were not available. Most of the literature review came from academic digital libraries such as ABI/INFORM Global, ProQuest database and EBSCHOST database. In situations where peer-reviewed journal articles did not supply enough background data, other Web-based resources were reviewed.

\section{Historical Background of FDI in Cameroon}

The involvement of MNEs in the Cameroon economic activities can be traced back as early as 1884 when Germany annexed the territory that would later become Cameroon (Njong, 2008). During this period, the Europeans viewed the annexation of Cameroon as a good source for their agricultural products. Cameroon was no exception when the Germans established big corporations to produce both cash and food crops in the country from the plantations. After Germany's defeat in World War 1, Cameroon was partitioned between British and French under the trusteeship rule of the League of Nations in 1999 (Njong, 2008). The British and the French territories later united to form the present Cameroon. Forgha (2009) declared that years after independence, FDI was "perceived as an evil that negatively influenced internal decision making, induced loss of control over domestic policies, and imported obsolete technology" (p. 10). The policy makers' perception caused the Cameroon leaders to naturalize all foreign companies and to place a greater control of all private and public sectors in the Cameroon economy. Forgha continued that however, foreign investors still participated in economic affairs of Cameroon through joint ventures and equity holdings. The indirect participation of foreign firms through equity holdings, accounted for the inflow of FDI into Cameroon until the 1980s.

Prior to 1989, the Cameroon government practiced a clear protectionism; with about 20 different taxes selectively on imports and export products. In many cases, tax rate was as high as $150 \%$ of the cost insurance-freight value [30]. The tax rate was drastically reduced after 1989, following the execution of the Structural Adjustment Programme (Njong, 2008). To further improve and promote foreign investments, the government implemented the proposal by the Central Africa Economic and Monetary Community (CEMAC). The proposal was followed by the devaluation of the CFA franc (Cameroon currency) in 1994. There were other similar policies such as the privatization of the oil sector investment.

There had been continuous efforts by the Cameroon leaders to encourage more FDI into the country. Over the years, the leaders enacted a series of legal instruments to encourage and boost FDI inflow at the national level. Such instruments included the Investment Code of 1990, amended in 1994; the Patent Rights Act, also called the Bangui Agreement, initially enacted in March 1977 and amended in February 1999; the Paris Convention for the Protection of and promotion of Industrial Property of 1883 , revised in 1990; and bilateral investment treaties for the protection and promotion of investments signed in 1966 (Forgha, 2009; Njong, 2008).

There was also the investment reform policy in Cameroon to attract more FDI. Some of the policies began in 1963, when the Societe National d'Investment (SNI) was created and was later resolved (Forgha, 2009). Under the SNI, the State was to take a greater part as a shareholder in any large private, forming a joint venture with the private firm. New investment policies were introduced between 1990 and 2002. One of the policies emphasized the need to process primary products before they were exported, and the encouragement of competition among firms. The National Industrial Free trade Zone and the Investment Code management unit were created to support the SNI policy. The two structures were to formulate and enforce policies to attract and encourage both foreign and domestic investors through tax relieve policies [31]. The enactment of these decrees, laws, and policies, Cameroon attracted more FDI inflow. However, the increased FDI inflow did not generate enough economic growth; which resulted in high unemployment, poor technological advancement, and poor standard of living [32]. There has been an upward trend for net FDI inflow into Cameroon in recent years. The net FDI inflow into Cameroon peaked at 305 million (Unite States dollars) in 1985 before it peaked at negative US \$128 million in 1990. In 2009, the annual average FDI flows into Cameroon was US \$337 million dollars, but with no major improvement on the economic growth [33]. Many researchers have focused on the determinants of FDI inflow in Cameroon (Forgha, 2009; Kumo, 2009) but a few researches on the economic growth in Cameroon (Ajayi, 2008). To address this research gap, this qualitative study was to explore FDI inflow into Cameroon in terms of their effects on economic growth, focusing on the period between 2006 and 2010.

\section{Foreign Direct Investment and Economic Growth}

Many scholars such as [34], have applauded positive effects of FDI on economic growth, especially in developing countries such as Cameroon. An empirical study 
on 25 African countries between 1998-2007 [35] finds that FDI has a positive effect on the economic growth in those countries. In another research on 33 developing countries [36], shows a higher economic growth with the increase inflow of FDI. In addition, [36] found from the study that the marginal contribution of FDI was greater than that of domestic investment. According [37], FDI is an important source for technology transfer which contributes more to growth than domestic investment. However, some scholars such as [38] contested the assertion that FDI generally generate economic growth. Dutta \& Roy, (2011) posted that empirical evidence concerning developing countries such as Cameroon shows that FDI do not create economic growth. However, FDI may directly affect the economic growth of developing countries. A typical means by which FDI can affect a country's economic growth is the improvement of human capital. This is done by the transfer of their ownership advantages such as management skills, technological know-how by means of training of local new hires, and spin-offs. Multilevel data from 34 countries were gathered during the period 2002-2005. The researchers found that a country's proportion of export-oriented new ventures affects the subsequent emergence of new business, as a result of knowledge spillovers from FDI.

\section{Foreign Direct Investment}

In the past two decades, there have been advances toward a truly global economy driven to a large extent, by the role of Multinational Enterprises (MNEs) and their activities around the world [39]. FDI is the movement of both human and financial capital over national borders in such a way that they provide the investor full control over the acquired asset [40]. Therefore, FDI is different from portfolio transactions which may cross borders, without providing such a control over the capital acquired. Expressed their views of FDI as follows [41]:

FDI is a category of international investment that reflects the objective of a resident in one economy (the direct investor) obtaining a lasting interest in an enterprise resident in another economy (the direct investment enterprise). The lasting interest implies the existence of a long-term relationship between the direct investor and the direct investment enterprise. Direct investment includes subsequent capital transactions between the investor and the direct investment enterprise, and among affiliated enterprises resident in different economies (p. $10)$.

[42] stated that in recent year, there has been an upward trend on the global expansion of FDI, US with $\$ 233$ billion in 2004; it almost reached the 2001 peak. However, Meyer continued that FDI in emerging countries are not equally distributed; Meyer stated that China accoun- ted for US \$61 billion, while Africa attracted only US $\$ 18$ billion, which are not equally distributed. The progress in FDI has raised many controversies in the ways these foreign investors conduct their businesses in the developing countries. According to Meyer, foes of internalization view MNEs to be the root cause of the downfall of world economic progress, ranging from continuous income inequality, sweatshop working conditions, and environmental pollution. Supporters of MNEs conversely, contents that the benefits of MNEs cannot be overemphasized including the sharing of skills and technology worldwide. It also includes lowering prices to consumer items, and the transfer of knowledge from the technologically advanced countries to the emerging countries [43]. According to (Meyer \& Sanai, 2006), emerging countries offer more incentives when compared to the developed and advanced markets. These incentives help the MNEs to spread out their investment risk in these unpredictable emerging economies.

There have been some studies on FDI and its effect on output and growth. [44] conducted an empirical study to examine if financial sector development is important precondition for FDI to enhance economic growth in 44 Asia and Oceanic countries for the period 1996-2005. The study also examined if the effect is dependent on the stages of development of the countries. The empirical analysis showed that financial sector development enhances the contribution of FDI on the economic growth in the region. It also showed that the complementary role of FDI and financial sector development on economic growth is most important for least developed economies in the region. Researchers have concluded that there are positive effects of FDI on economic development, but why such growth is very slow in Cameroon is the concern of the research. There are studies related to FDI flow to Africa such as: (Njong, 2008; Forgha, 2009). While most of the higher rates of FDI inflow occur in many developed and other emerging countries, it is significantly slower in the African developing nations (Kumo, 2009). United States is the highest beneficiary of FDI. According to United States Bureau of Economic Analysis (2009), more than $\$ 325.3$ billion in FDI flow into the United States in 2008. Nevertheless, in recent years, there has been steady but slow progress of FDI in flow into Cameroon. In the past 6 years, FDI inflows into the region reached US \$53 billion in 2007 (Jenkins, 2009).

FDI plays a major role in the economy of Cameroon but a reliable data of FDI in the country is not readily available (US Department of States, 2009). France and The United States are two major FDI participants in Cameroon. According to the US Department of States, The US FDI stock in Cameroon is rising. Most of United 
States investment in Cameroon is in the petroleum sector. Jenkins (2009) stated that the Chad-Cameroon pipeline which runs from Chad's Doba oil field, is one of the largest US investments in sub-Saharan Africa. Exxon/ Mobile and Chevron/Texaco team up with Malaysia's Petronas to undertake this giant project. Other US MNEs operating in Cameroon are Dole that has equity in a French firm to produce bananas; Del Monte with a US stake is also producing bananas in Cameroon. Additionally, Golgate-Palmolive is producing oral care for the local and regional market in the Cameroon plant. France continues to be a major force of investment in Cameroon. In the banking industry, France's banks are dominants in the country. According to the [45] there are about 160 French branch companies in Cameroon employing some approximately 30,000 people and more than 200 enterprises owned by French nationals.

Acs, Braunerhjelm, \& Carlson, (2009) reported that many economists have examined the size and various other characteristics of the host market, as well as the nature of the MNEs and the investment to explain individual decisions to invest in international market. Factors such as the market size of the country, availability of labor, and other important factors are considered. The size of the host market and level corruption in the country play important role in attracting FDI to a country [46]. The larger the market of a country, the more encouraged foreign investors is to invest in that country. However, many view political instability and democracy as one of the major determinant factors that attract FD (Jajri, 2009; Acs, Braunerhjelm, \& Carlson, 2009). The frequent coup d'état in many African countries, in addition to frequent tribal wars and unfair election practices deter many MNEs from investing in Africa. While many researchers focus on factors attracting the flow of FDI to developed countries, studies exploring the effects of inflow of FDI on economic growth in Cameroon are rare. Other recent researchers have found that democracies, GDP, and exchange rate attract more FDI [47].

Due to the global economic crisis, the debt and financial crises of developing and emerging countries have caused a deep appreciation for FDI. Short term-loans and portfolio investments remain volatile and risky for developing countries. Moreover, foreign aids are shrinking; developing and many emerging countries are increasingly turning to FDI for their economic growth. FDI is considered successful and almost risk-free for gaining foreign exchange and getting access to new technology. International institutions such as International Monetary Fund (IMF), the World Bank, and the Organization for Economic Corporation (OECD) highly recommend FDI to the developing and emerging countries for a sustainable source of economic prosperity (UNCTAD, 2009).
FDI is believed to promote export production and encourage foreign exchange, which may result in easing the balance of payment problems. Through the introduction of new production processes, FDI is expected to create new jobs (David \& Nigel, 2007). As an important part of economic growth and development in the developing and emerging countries, FDI is also expected to stimulate the revenues in the host country through the additional corporate revenues and personal income tax revenues. FDI is considered by many as a significant source to stimulate economic growth of a country. The spillover of technology and knowledge from multinationals to the host country, are expected to improve the productivity of local firms $[48,49]$. The aim of the technology and knowledge transfer is to improve the economic condition of the host country, which would result in increase in the GDP of the country [50].

Global flow of FDI reached a record amount of $\$ 1306$ billion in 2006 (United States Department of States, 2008). The recent increase in FDI has been attributed to an increase in cross-border mergers and acquisitions, the value, which was about $\$ 1637$ in 2008 [51]. Realizing that FDI is a major source of employment, income growth, and economic development; many developing countries in Africa including Cameroon, attempted to improve their business environments to attract foreign investors [52]. One means by which they have done so is enacting policy reforms that liberalize their foreign trade and investment regimes and privatize many state companies [53]. The pace of their reform has accelerated since the Asian crisis in 1977 and the current global economic crisis that began in the fall of 2007. However, many emerging countries, especially African countries, have been unable to attract increased FDI and several that has attracted more FDI such as Cameroon, have not seen a commensurate increase in economic growth. Even after reforming many economic policies necessary to attract more FDI, Cameroon has not experienced sustained economic growth.

\section{FDI Inflow into Africa}

Many African countries including Cameroon see FDI as important to their economic growth and development. They understand that FDI will provide the much needed capital for investment, provide aids to the local firms to be more stable, productive and by adopting modern, and efficient technology or by investing in human capital [54]. Moreover, majority of the fast growing countries depend on capital from FDI to support the transformation of their growing economy. Developing countries from Africa including Cameroon need such investments to accelerate their efforts in economic development [55]. 
It is the hope and belief of the developing African countries such as Cameroon that more inflow of FDI into the region would improve the much needed higher standard of living through the creation of employment opportunities. Most African countries have instituted many policies to attract more FDI. African leaders expect that FDI would produce external help in the form of technological transfer and spillovers. The pursuit of responsible macroeconomic policies combined with an accelerating pace of liberalization, deregulation, and above all, privatization were expected to attract FDI to Africa (Ajayi, 2008). Ajayi continued that despite many policy changes such as deregulation, and privatization, the continent of African has not benefited significantly from FDI to commensurate to its policies in favor of FDI. However, there is a positive trend towards a rise in FDI inflow in Africa in recent years.

Other developing countries such as Nigeria, Angola and South Africa, Congo Republic, and Equatorial Guinea continue to attract more FDI, largely because of their rich in natural resources. Lately, FDI has diversified into other sectors such as manufacturing and services. Mauritius is able to attract more FDI into the manufacturing sector through its textile industry. Ajayi (2009) also added that, in the last decade, Morocco has witnessed its share of FDI increased greatly in the manufacturing and service sectors. The sources of the FDI vary largely due to the needs of foreign investors. According to (United States Department of States, 2008), FDI from Germany has been mostly in the manufacturing, British FDI in the service and manufacturing, and the United States in the exploration and service. [56] reported that recent surveys of the multinationals indicate that tourism, and natural resources industries have the greatest potentials to attract more FDI into the region. In recent years, telecommunications has attracted more FDI in the region than ever. This is mainly because of the privatization in the telephone companies in many African countries such as Nigeria and Ghana, and the emergence of global system of communication (GSM) in some African countries (Ajayi, 2008). Despite many policy changes, laws and other legal instruments instituted in African countries including Cameroon to attract more foreign investors, there is still disproportionate economic growth from FDI in the region. Ajayi explained that one of the reasons for the African predicament situation as follows:

Africa has not been able to attract enough foreign direct investment to commensurate with the fact that the rate of return to investment in Africa has not been found to be higher than other developing countries. This is because investment in the continent is viewed as a high-risk activity due partly to the negative perception of Africa: perception of its political and economic activities and the poor infrastructure facilities in addition to the absence of adequate legal framework for the enforcement of contracts. Too often, potential investors shy away from Africa because of the negative perception of the continent. This outright condemnation of a whole continent conceals the heterogeneity of the continent and the complex diversity of economic performance and the existence of investment opportunities in individual countries (p. 7).

However, there has been a surge in recent years in private capital flows into developing African countries. Many African countries such as Ghana and South Africa are attracting FDI and experiencing economic growth. As a result of their respective economic policy framework, great business atmosphere is created by the policy makers. Countries such as Angola and Mozambique are becoming more attractive to FDI due to their mineral production and good economic policies, which result in better economic growth (UNCTAD, 2008). FDI inflow exceeded $\$ 1$ billion in eight African countries, and rose in 33 countries in 2008 (United Department of States, 2009). FDI increase is also noticed in the primary sector, oil, gas, and mining in recent years. In addition, northern Africa has experienced unprecedented surge in the manufacturing sector. In 2007, many African countries incorporated certain steps in their regulatory framework to attract more FDI. The measure ensures steady inflows of FDI, which have the most positive effects on their economic growth. There are positive prospects for FDI into Africa because of high commodity prices in the global market.

However, there is a problem of inadequate information and knowledge in the business world about the much improved governance and excellent business atmosphere in many African countries. A number of studies have been done on the determinants of FDI in Africa (Lemi \& Asefa, 2009). In a few cases, the determining factors to attract FDI into Africa are different from other parts of the world. Lemi \& Asefa (2009) declared that determinants that attract FDI in other countries may not be successful in Africa. It is also found that the determinants of FDI in Africa are mostly controversial and contradictory.

\section{Determinants of FDI}

In recent years, economic and political policymakers in developing African countries, especially in Cameroon, have realized that FDI is the key to achieve economic growth, and political stability. It is claimed that FDI can create employment, increase technological development in the host country and improve the economic condition of the country in general. Cameroon, similar to other African countries does not have enough resources to fund major capital projects. According to (Buthe \& Miller, 2008), the lack of adequate funds will cause Cameroon not to accomplish the Millennium Development Goals 
(MDGs) by 2015 dateline set by the United Nations. The government of Cameroon has come to understand that FDI is the ultimate means of acquiring capital for the project. That is the reason why all the incentives and new laws are enacted to attract FDI into the country.

Risk opposed investors favor an environment with less uncertainty. Social, political and economic stabilities are therefore critical in attracting foreign investment. Despite its unlimited profitable potentials, Cameroon and other African countries are faced with the problem of attracting more foreign investors into the country. Wahid et al. stated that the volume of FDI that flows into Africa is relatively low as a share of the total global FDI flows, and as a share of FDI flows into all developing countries. African countries are generally viewed as politically unstable due to frequent religious and ethnic conflicts and also random military interruption in political politics. [57] argued that despite institutional and economic changes in the African countries within the past decades, FDI flow to this continent continues to be lower than other continents'. However, contrary to conventional wisdom, political rights and infrastructures were found to be less important for FDI inflow to Africa. The level of corruption in the host country is one of the major determinants of FDI inflow into a country, hence low economic growth [57]. (Al-Sadig, 2009) reviewed an empirical study conducted in East European transition economies with no outward FDI before 1995. The study was to find out the effects of corruption into those on FDI location decisions and those on the FDI size. Al-Sadig found a linear and negative relationship between host country corruption and the likelihood of MNEs locating in that country. It was found that, the relationship between host country corruption and FDI is non-linear, with both low levels of corruption in the home country reducing the probability of the outward FDI flows. It was concluded that if FDI is undertaken in a given host country, the volume of FDI is not affected by host-country corruption.

Cameroon suffered a terrible violence in 2008 when transportation workers went on strike. As reported by the transportation workers' strike for better benefits, eventually became a country-mass protest. The citizens ceased the opportunity to protest against President Biya's intention to amend the constitution to favor his longer term in office. The unrest stalled major economic and political activities including a major port in Duala for few days. Some of the targets during the protest were on the government and some business establishments. Such a random civil unrest discourages a lot of MNEs who undertake FDI. Instability in microeconomic factors such as excessive budget deficit, double digit inflation, frequent currency crashes are also determinants of FDI inflow into a country. MNEs are not particularly encouraged to in- vest in such countries where there is a high production cost due to inflation. Foreign investors would be reluctant to invest in any country where the value of its currency changes arbitrarily, and the market cannot support the product of their products. Ajayi (2009) pointed out that exchange rate is often cited as one of the determinants of FDI. There is exchange rate risk involved in the repatriation of profits and investors will prefer to invest in countries with strong currencies. In addition, the absence of transparency in a country's macroeconomic policies, which inhibits specific government policies, is a great concern to foreign investors. Frequent changes in such policies without notice by many governments would discourage FDI. In many developing countries, it is difficult to know a specific economic policies; such a situation makes it difficult for investors to formulate sound investment strategies. [58] reported that African countries with high inflation and other discouraging economic factors attract less inflow of FDI.

The openness to trade, including low bureaucratic barriers, will be appealing to foreign investors. According to the UNCTAD (2009), the government of Cameroon provides clear business laws in theory, but implementing the laws prove to be changing. Under the 2002 Charter, the government of Cameroon is simplifying its tax assessment and collection to apply equally to all tax-payers. The effort is to assure MNEs and the local investors that the system is transparent; that would encourage investors to operate in Cameroon. In an early stage of economic development, a country's main location advantage is likely to be low labor costs rather than a large domestic market. Infrastructure plays a great role in attracting foreign investment in a country. Access to good communication networks is of importance to most MNEs looking for a great host country. China has been successful in attracting FDI in part because it provides excellent infrastructure to investors, particularly in its export processing zones. The absence of excellent roads, dependable power supplies and skilled labor discourage FDIs for high cost reasons. Good road network including railroad would encourage many foreign investors into a country. Modern infrastructure such as telecommunications and rail road network would make it easier to transport finished goods to the port of export. Ajayi (2009) summed it up that "the more developed the road system in a country for example, the easier the access to markets and the lower the transportation costs, and thus, the greater the incentives to invest in the country" (p. 92).

Geographical and perhaps historical and cultural proximity to large and growing market is an important advantage for a less developed country like Cameroon in attracting FDI. In order to keep transaction costs low, firms should seek to decentralize the production chain. 
Many of the emerging countries such as Cameroon do not have a large market to attract FDI. Regional enhanced integration will be necessary to generate the size of market needed to attract MNEs into the countries. Moreover, a creation of an active and functioning economic community in the region will be a great idea for an area that is marred with the credibility of economic policies (Kumo, 2009). The formation of a regional grouping will be a good tool for the resolution and prevention of regional conflicts in the emerging countries such as Cameroon. The improvement of these amenities, will reduce cost of provision of the facilities, increasing trade, hence encourage and attract foreign investors for economic growth.

In the case of political variable, FDI are more attracted to democratic countries than the autocratic [59]. Private investors are more concentrated in democratic due to conducive and supported business climate such as governance and institution. Natural resources are also another determinant of FDI inflow into a country. Countries rich in natural resources such as South Africa and Nigeria tend to attract more FDI than those with little or no natural resources. It does affirm the fact some developing countries with more natural resources attract more FDI and are more capital intensive. With Nigeria a lot of oil, there are many foreign companies such Shell, Exxon Mobil and other oil related foreign firms for the oil exploration. There is also a close relationship between FDI and manufacturing wages. As reported by Guerin \& Manzocchi (2009), countries with above average wages tend to attract more FDI and better economic growth. This may be as a result foreign companies paying higher than legal minimum wage, because of their higher capital advantage over the local firms.

In addition, FDIs are more attracted to countries with liberal labor market regulations and rigidity in hiring and hours of operations (Karim \& Ahmad, 2009). Countries with strict labor laws that prevent dismissal of workers; firms would not have the motivation to hire new workers [60]. Such laws will also discourage foreign investors into the countries (UNCTAD, 2009). Karabay (2010) pointed out that flexibility in labor market has positive effects on the FDI inflow into a country.

\section{Challenges and Trends of FDI}

The current global economic and financial crises pose great challenges to FDI. The section will address some of these challenges; from home and host countries perspectives that MNEs would anticipate. One of the most outstanding challenges is human resources. Establishing a well-trained and international production network is significant facing MNEs. The challenge is even greater in the emerging countries with less skilled labor. The emerging countries with needed skilled labor have advantage of attracting more new FDI. The success of MNEs would more likely depend on their ability to build management skills, understand and adapt to the international markets. In addition, FDIs are faced with the challenge to adjust to the management styles especially in the emerging countries with less time to develop the needed capacities and skills [61]. Recently, emerging countries' MNEs have undertaken outward foreign direct investment (OFDI) [62]. These countries are less likely to have built up expertise and capacity in integrating acquisitions and managing foreign affiliates. Sometimes, the lack of management to sacrifice their comfortable life-styles in their home country to work abroad, also threaten the success of the FDI.

Another challenge is the balancing of opportunities and risks in the global markets. However, the dynamic and unpredictable condition in the international market in many instances will lead to a more global economic competition (Sauvant, Maschet, \& McAllister, 2009). In today's international market, high debts, along with unpredictable commodity prices creates uncertain future for foreign investors. The levels of political risk in the developed countries are quite different to those of the emerging countries. Developing African countries find it very difficult to attract foreign investors into the area because of regular power struggles and coup de tats, hence political instability. Countries such as Nigeria, Ethiopia, Zimbabwe and Kenya with frequent political unrest cannot adequately compete with China and Ghana in attracting more FDI (Kumo, 2009). FDI regularly are faced with some pressures from the stakeholders either on performance or in decision making situations. A major source of pressure or problems to FDI is the host country. According to (Guerin \& Manzocchi, 2009), a host country may levy high taxes on MNEs, which may affect the shareholders rate of returns. The host company's employees may form labor union and stage a strike against a foreign firm. Such action would result to loss productivity, and revenue to the firm. Guerin and Manzocchi (2009) continued that MNEs may face organized robbery or kidnap of the expatriates for ransom. These and other undue restrictions would discourage or impede the progress of FDI into Cameroon and other developing countries. In the developing African countries, economic and political instability, poor communication system and poor government policies pose major crisis for these countries to effectively attract FDI (Kumo, 2009). Kumofurther reported that:

At the end of 2007, political instability and conflicts were limited to few countries, viz., Sudan, Somalia, Zimbabwe and Ethiopia. In 2008, the disputed election in Kenya that threatened to derail the country's democratic process, disputed elections in Nigeria, the coup de tat in Mauritania, and in Guinea, disputed elections in Angola 
and Zambia all undermine the image of the continent and its competiveness in attracting FDI (p. 3).

The OFDI from the emerging is faced with lack of support from the home countries. There is little or no policy framework to support the firms to compete effectively in the global completive business arena. However, the lack of government support is restricted by their limited resources, potential concern over the export of capital and jobs and scarce foreign reserves [63]. There is a huge contrast in the lack of supportive framework in developing countries compared to the developed countries. Developed countries have built long standing strong and sustained policy framework complimentary to their economic condition. Some of the policy framework includes the followings: fiscal incentives, financial support, provision of information and technical support, investment insurance, and official development assistance programs [64]. Although the emerging market MNEs may be willing to adopt most policies from the developed countries, their strong influence by their home government make it rather impossible. China has successfully proved to be one of the few emerging countries to address the challenges from home country policy. China has successfully changed the country's policy from OFDI restriction to promotion. The increased protectionism, mostly from emerging MNEs is making the acquisitions in developed countries difficult. The control of the acquiring firm by the home government may raise a great concern by the host country (Karabay, 2010). The host country may feel that the acquisition may be politically driven rather than with commercial motives. Protectionism if left unchecked, could damage the integration and functioning of global economy. The many advantages of FDI such as a source by which the host countries acquire technological assets and new management techniques should be of particular importance to the host country (Karabay, 2010). Another challenge facing FDI is corporate social responsibility. It is crucial and appropriates that FDI live up to expectations to fulfill the basic expectation. The workers to the firms and the citizens of the host country in general expect foreign firms to provide descent work environment, respect for human dignity and avoid air and environmental pollutions. The challenge of doing what is right ahead of super normal profit is one of the huge challenges facing FDI. To some, host country regulatory characteristic in addition to certain features of investor's corporate governance post a new set of challenges for FDI (Haglund, 2008).

A few years ago, FDI from the developing countries was about $5 \%$ of the total global FDI (Sauvant, Maschek, \& McAllister, 2009). Sauvant, Maschek, \& McAllister, 2009) continued that the Russians introduced the right to private investment to spur up economic development in the region. The current world financial and economic crises have caused a significant decrease in FDI even in the developed countries. Karabay (2010) declared that, FDI inflow "at a time of decreasing FDI flows and increasing competition for these flows represent a significant challenge for investment promotion agencies" ( $p$. 22). In recent years, it has been increasingly difficult for MNEs to embark on FDI due to the current unpredictable global economic and financial situation. Foreign investors are faced with making tough investment decisions on where and when to invest. Bridging the gap among the corporate structure remains one of the challenges facing MNEs from the emerging countries, seeking to invest in the developed countries. The ability to negotiate, adapt to the culture and the practices in the developed countries are great potential challenges to the leaders of the MNEs.

Amin (2007) stated that this is a direct result to better economic and political stability in many countries of the world. In 2006, there was a record of \$1306 FDI transactions in the world; international mergers and acquisitions (M \& As) had the biggest increase in 2006 (Sauvant, Maschek \& McAllister, 2009). According to Sauvant, Maschek \& McAllister, almost all the regions of the world experienced the growth of FDI inflows. They explained that East and South Asia is experiencing increase of FDI. The Caribbean and the Latin America are noticing a double digit increase of FDI inflow into the area. African continent also made a significant increase in attracting FDI in 2006 according to. Sauvant, Maschek\& McAllister (2009) concluded that China, Hong Kong Singapore was among the top racked countries that had FDI increase in 2006.

There are continuous changes in the global environment for FDI. Changes such as competition among firms from all over the world, has provided more opportunity to the firms from the emerging countries to embark on outward foreign direct investment (OFDI). There have been significant upward trend for OFDI in recent years. There have been rapid trends of OFDI in recent years. The emerging market MNEs are steadily making progress in the OFDI [65]. The annual Fortune "Global 500" ranks the top 500 MNEs across the world. In 2009, 86 companies in the list were from developing countries, compared to 69 in 2007 and only 19 in 1990 (Amighini et al., 2010). The internationalization process has provided a link to the inward FDI activity at home; which the local firms have been able to establish global network (Li, 2007). [66] emphasized the need for the emerging countries MNEs to capitalize on the inward FDI joint ventures; their participation in the global value network chains and become more competitive in the global market (UNIDO, 2006). UNIDO explained how many Asian subcontractors in the field of information technology 
have prospered as contract manufacturers mostly in the fields of information technology, and consumer electronics. This is as a result of their learning and innovative efforts; many of them are becoming the original brand manufactures in a pattern of development and globalization.

The OFDI flows from the emerging countries particularly from the BRIC (Brazil, Russia, India and China) economy (Sauvant, Maschek, \& McAllister, 2009). Asia has surpassed Latin America and the Caribbean to achieve the dominance position for the MNEs engaged in OFDI from the emerging countries.

The Chinese OFDI flows continue to be on the upward trend, and reached US\$96 billion; in 2008, global OFDI more than doubled to US\$51 billion (Sauvant, Maschek, $\&$ McAllister, 2009). As a result of a strong demand for oil and other natural resources, oil has become a formidable source of investment in many oil rich African countries such as Nigeria and Cameroon. Recent criticism is that the rising number of the OFDI mostly firms from the fast growing emerging countries of the Asian Pacific region [67]. This makes it difficult to extend it to many other emerging countries such as Cameroon the world also reflect a better economic environment in the presence of economic reforms and investment-oriented policies. Global flow of FDI reached a record level of $\$ 1306$ billion in the 2006 (UNCTAD, 2009). The increase in FDI could be attributed to more cross border mergers, cross border mergers and acquisitions. The value of mergers and acquisitions amounted to $\$ 1637$ billion, 21 percent higher than the previous record of 2006 (UNCTAD, 2009).

\section{Research Methodology}

\section{Research Method}

Cameroon and many developing countries are experiencing the problem of economic growth (Njong, 2008; Forgha, 2009). The increase in FDI inflow into Cameroon has failed to generate more economic growth to meet the expectation of the Cameroon leaders. The problem addressed in this qualitative case study was that the increased inflow of FDI into Cameroon had failed to lead to higher economic growth in the country (Njong, 2008). The purpose of this qualitative case study was to explore the reasons why the increase in FDI has failed to generate more economic growth in the country.

Important information was from the response to the primary question that asked why increased FDI had failed to generate higher economic growth in Cameroon. To explore the reason why the increased inflow of FDI into Cameroon has not led to a commensurate increase in economic growth in the country, more investigation of this question generated the understanding of the follow- ing additional questions:

Q1: How do the missions of foreign investors affect the economic growth in developing countries such as $\mathrm{Ca}$ meroon according to investment managers in the energy, health care, technology, and financial industries in the United States?

Q2: How do foreign investments complement economic growth and development in Cameroon according to investment managers in the energy, health care, technology, and financial industries in the United States?

Q3: How do higher inflows of foreign investment affect the economic growth, technological, and educational development of Cameroon according to investment managers in energy, health care, technology, and financial industries in the United States?

Q4: What policies are foreign investors engaging in to generate economic growth in a developing country such as Cameroon according to investment managers in the energy, health care, technology, and financial industries in the United States?

The study participants, the appropriateness of the study design, collection, analysis and the validity and the reliability concerns were addressed in this chapter. In addition, ethical assurances were presented in this section of the dissertation. A single case study was applied in this study because of the real value in studying an institution in depth [68]. A single case study provided value for studying one institution in detail. The one institution in this study is Cameroon; other developing countries may be considered in the future studies to generalize and verify findings [69].

\section{Participants}

A stratified sample of 20 investment managers was purposefully selected for this study. Five participants came from each subgroup of energy, financial institutions, health care, and technology. Each participant had 20 years or more experience in their respective areas and the knowledge of the study region. The researcher had first purposefully compiled the list of 100 MNEs located in the United States from the U. S. business directory database. In addition, the names of the investment managers from these MNEs and their email addresses were compiled. Out of this accessible population of 100 individuals located in various states of United States, 30 were contacted and their permission sought to participate in the study. The researcher explained to these investment managers the purpose and the significance of this study. Twenty of the 30 managers, who were randomly selected, voluntarily agreed to participate in the study. These participants represented each of the subgroups of energy, health care, financial institutions, and technology. Each of the subgroups was represented by five different companies, and 
each with one participant.

The specific sample was from MNEs, which are doing business in Cameroon. The participants were to have the experience and knowledge in the region to provide vital information about the issue of poor economic growth in Cameroon. These experienced participants were committed to provide unbiased and accurate data necessary for this study. The sample size was determined by the selection of sampling units from each of the employment organization. The purposeful sample ensured that the study design included the right position distribution within the business groups. A purposeful sampling was used to allow real concentration on participants and interview questions at the same time facilitating the case study [70]. Job position and experience were some of the characteristics considered on the stratified purposeful sampling.

\section{Methodological Assumptions, Limitations and Delimitations}

The main assumption to the study was that the data that were to be gathered and the subsequent findings from the data were to be able to answer the research questions in order to contribute to the understanding of the effects of FDI on developing economies, especially in Cameroon. A second assumption was that the participants were to be capable of answering the interview questions, and were to do so truthfully and accurately; hence the selection of the investment managers from diverse MNEs and their moderate global investments experience. A major methodological assumption was that the findings were to benefit other African developing and emerging countries, hence assuring external study validity. Another limitation was the possible inability of the participants to provide unbiased answers to the questions, a major challenge in qualitative research. Nevertheless, qualitative data analysis is prone to bias than any other analytical methodologies; any potential bias was resolved during the data analysis. A major limitation is the lack of inclusion of representatives of the Cameroon government in order to gain understanding of their perspectives of FDI on economic growth in Cameroon. Nonetheless, it is the multinationals that need to express the reasons why their investments are not yielding more in Cameroon. For that reason, it was appropriate to interview the diverse MNEs rather than the Cameroon policy makers.

\section{Evaluation of Findings}

The purpose of this qualitative case study was to understand the reasons why increased FDI has not led to higher economic growth in Cameroon. Cameroon leaders believed that FDI was to be the major medium of technology transfer (Njong, 2008). This study was encouraged by the deteriorating economic growth in Cameroon despite increase of FDI inflow into the country (Forgha, 2009). The data for this research were from structured telephone interviews with 20 investment managers in the United States. The theoretical framework of the study was based on the assumption that FDI generates economic growth in the developing countries such as Cameroon. The endogeneity growth theory was used to guide the collection and analysis of the data.

The results of the data analysis from the telephone interviews generated factors such as bribery and corruption; economic and political factors, and bureaucracy as possible reasons for the slow economic growth in Cameroon despite higher inflow of FDI into the country. The empirical evidence gathered during this study did not support the assumption that FDI generate economic growth in developing countries such as Cameroon. In addition, because the study was conducted only on Cameroon, its applicability is restricted to the degree to which expanding into other developing countries by the investment managers is conceptually accurate. It is widely supported by many economic scholars that FDI generate economic growth in the developing countries such as Cameroon (Ahmed \& Eden, 2009). The analysis and findings of the study are hereby presented using the research questions as the framework.

Research Question 1. A review of the literature indicated that the poor economic growth in Cameroon despite the high in increase of FDI in the country is a well known problem. However, little studies are done to address the issue. A previous related research found that FDI's main motive is not to provide employment opportunities and transfer of technology to developing countries such as Cameroon [70]. The technology, knowledge transfer and employment opportunities are nothing but the means for profitability and extract of the natural resources to benefit giant foreign companies and their shareholders and not for the benefit of the developing countries such as Cameroon (Eden, 2009). The transfer of such technology and job creation is always insignificant as the study indicated. Forgha (2009) declared that years after independence, FDI was "perceived as an evil that negatively influenced internal decision making, induced loss of control over domestic policies, and imported obsolete technology" (p. 10). Many differences exist between this study and other previous studies. The purpose of was to explore the best management practices for corporate, academic and governmental transfer of sustainable technologies to developing countries. This study in contrast, intended to understand the reasons why increased FDI has not led to higher economic growth in Cameroon. In addition, this study only focused on one developing country, Cameroon. [71] extended their studies to include many other developing countries in Asia Africa and Latin America. 
In addition, the structured telephone interviews in this study were about the reasons for the poor economic growth in Cameroon. This stands in contrast to Rochon, Niyogi, Quansah, Biehl, \& Araya (2010) who relied on predetermined questionnaires. As mentioned in the theoretical framework, more research is needed to find out if the framework from is relevant to the reasons for the poor economic growth in Cameroon despite the higher inflow of FDI into the country. All the 20 investment managers $(100 \%)$ expressed concern over bureaucracy and $95 \%$ reported bribery and corruption as possible factors for the poor economic growth in Cameroon. From the initial study finding, there was the possibility of a relationship between bribery and corruption and bureaucracy with the poor economic growth in Cameroon. The result of such a relationship may be beneficial for Cameroon and other developing countries to re-evaluate governance as important factor for their economic growth.

Research Question 2. The explanation on how FDI complement economic growth in Cameroon was addressed in Research Question 2. The endogeneity growth theory posits that there is a positive relationship between FDI and the economic growth in the host country (Francis, 2006). Previous studies such as Njong (2008) showed no close relationship between FDI and economic growth in Cameroon. In addition, there was no statistical match found between poor communication systems in Cameroon to the effects of FDI on the economic growth in the country. However, more than $90 \%$ of the participants stated that their organizations provide financial and technical assistance to their affiliates in the country; while getting tax breaks from the Cameroon government. The reason for the poor economic growth was examined in. The participants to this study were investment managers from four subgroups of businesses in the United States. A significant finding in this study showed that $85 \%$ of participants revealed that labor was necessary for effective operation in Cameroon. Educated and skilled workforce in the country responded well to training and development.

Research Question 3. Research question 3 addressed how higher inflows of foreign investment affect the economic growth and development in Cameroon according to investment managers in energy, health care, technology, and financial industries in the United States. One prior studyUttama and Peridy (2010) was consistent with the views of the participants of this study that the higher inflow of FDI in developing countries such as Cameroon positively affects their economic growth. However (Amighini, Rabellotti \& Sanfilippo (2010) conducted a multi case study which included many developing countries. In contrast, this study adopted a single methodology, which centered only on Cameroon. All the 20 participants $(100 \%)$ in this study reported that their presence in Cam- eroon have positively affected the employment situation in the country.

In addition, $95 \%$ of this study participant indicated that their affiliates have learned from the FDI the art of international marketing. According to these investment managers, many of the affiliates are able to directly sell their products in the global market. About $80 \%$ of the participants reported that the presence of FDI in Cameroon has provided the Cameroonians many choices in products and services. Findings of this study have mixed support, which emphasized exploitation of the host country's workforce and extract the natural resources as means of maximizing their profit margin to satisfy the shareholders. When asked about the reasons for the poor economic growth in Cameroon, all the 20 participants unanimously pointed to bribery and corruption and bureaucracy. This was consistent with the report from Forgha (2009) on the barriers to the economic growth in Sub-Saharan countries. Forgha (2009) found that paid public servants receive bribes to provide services to the public. It was also reported that extensive bureaucracy in the government, it takes longer time to issue permits for new business ventures. These and other factors contributed to the poor economic growth in the country.

Research Question 4. In research question 4, the participants were asked what policies foreign investors are engaging in to generate economic growth in a developing country such as Cameroon. Based on the information collected from the telephone interviews, the investment managers engaged in assisting human capital development in Cameroon. This is in agreement with OECD (2007) that FDI are avenues to integrate the host country into the global economy, mostly through financial flow from the home country. The integration in international market provided by FDI helped in the economic growth of the host country as they open up to the world market (United Nations Human Development Report (2008). Through integration, local suppliers are able to export their products to other world markets; either through the FDI brand or through their own brand. Other related interview results gathered showed that more than $80 \%$ of the participants asserted that political stability and market size are the major determinant factors to invest in developing countries such as Cameroon. In addition, all the 20 participants $(100 \%)$ perceived Cameroon to be one of the most corrupt countries in the developing nations. However, only $60 \%$ of the participants viewed Cameroon as a stable country.

\section{Implications, Recommendations and Conclusions}

Cameroon is one of the economies with a great demand for goods and services, which has attracted many fdi in 
2009, a higher fdi inflow of $\$ 337$ million into Cameroon generated an economic growth rate of $-1.5 \%$ (CIA worldbook, 2010). The problem that was addressed in this qualitative case study was that the increased inflow of fdi into Cameroon had failed to lead to higher economic growth in the country. This had resulted in a low rate of technological advancement, a high rate of unemployment, and a poor standard of living (Njong, 2008).

The data for this study were analyzed through coding, developing intuition and judgment, and developing themes and construct. However, the researcher's opinions, bias and exaggerations were controlled. Significantly, common themes to the participants were noted and served as nodes through the use of NVivo8 software [72].

\section{Implications}

The problem addressed in this qualitative case study was that the increased inflow of FDI into Cameroon had failed to lead to higher economic growth in the country. The overwhelming conclusions show inconsistency with the literature review and the belief that FDI generate economic growth in the developing countries. In addition the findings identified the possible reasons for the slow economic growth. The findings revealed bureaucracy and corruption as the possible challenges facing the economic growth of Cameroon. Other factors of concern for the slow economic growth were potential political instability due to disunity within the President's cabinet and party (Forgha, 2009). Bureaucracy and widespread bribery enabled inefficiency in the government to execute policies necessary for economic growth in the country. It is important to note that FDI provides among others, training, creation of employment opportunities to the Cameroonians, and help to expose local vendors to international market. However, corruption and bureaucracy stifle effective execution of sound economic policies. The telephone interview data analysis enabled the emergence of three core themes: a) eco-political; b) bureaucracy; and c) corruption. Exploring these themes enabled the identification of the reasons for the poor economic growth in Cameroon despite the increase in FDI in the country. According to the 20 research participants, eco-political factors directly affect the economic growth in Cameroon. Four research questions were addressed based on the evidence from the telephone interviews. The main implications of this research finding infer that though FDI generate economic growth in developing countries; it may not be possible in Cameroon because of widespread of bribery and corruption, bureaucracy and eco-political issues in the country.

\section{Recommendations}

From the research results, many recommendations are hereby offered. The first recommendation is that the government of Cameroon should introduce or execute any existing import duty relief Act. This Act should target imported materials for use in the manufacturing and processing of goods. The Act should reform import duty taxes and be crafted to protect domestic producers and promote manufacturing for export market. Good governance and free enterprises of business should be enforced. The scope for future empirical study to determine whether higher inflows of FDI into developing countries achieve higher economic growth is provided in this study. The second recommendation from this is that the Cameroon leaders should focus on improving human capital, financial market, and emphasize on export. The country must improve its financial market by removing financial restraints that hinder Cameroon firms from getting into export market. There should be a greater financial liberalization to enable the local business access to funds to meet their investment needs.

The third recommendation is that, for a country such as Cameroon, which depends mostly on FDI for economic growth, to ensure that their attention to FDI does not overshadow domestic small businesses. Local small businesses should be fully encouraged. Local businesses have closer contacts to the consumers and would generate faster economic growth than the large foreign investors (Ajayi, 2008). Fourthly, the country should invest on education, improve on the available infrastructure and the incentives promised should be fully fulfilled. Investment on education would not only generate more skill workforce, but would also increase the earnings of the labor, hence increase in the purchasing power in the local economy. In addition, Cameroon should recognize the effects of eco-political factors on the economic growth in the country. Eco-political factors include both political and economic factors. It is hereby recommended that the President instill stricter discipline on government officials. They should not live above the law, rather should work to restore dignity and respect to the country. A corruption tribunal should be set to enforce corruption laws and punish the culprits. More efforts should be engaged to eliminate bribery and corruption which have plagued the country for decades. Conflicts within the ruling party should be addressed to enable a full focus to the country's problems including the poor economic growth. A review of the findings shows that as many developing countries compete for more FDI with generous incentives, it is hereby recommended to Cameroon to assess the extent of FDI spillovers before the award of such incentives to the FDI.

Recommendation for Further Studies The findings for this research may not be generalized to other developing countries experiencing slow economic growth. The reasons for the slow economic growth in other developing 
countries may be different due to different settings. The first recommendation for future research is that the study should explore multiple developing countries with slow economic growth as against one country such as in this study. A second recommendation is that a larger sample of investment managers should be considered as participants from many developed countries. This would increase the amount of information gathered and may affect the findings.

The third recommendation for future research is multiple sources of data collection such as semi-structured interviews, surveys and published and unpublished documents. This would enable a better understanding of the reasons for the slow economic growth in Cameroon and for triangulation of the data (Yin, 2009). The fourth recommendation for future studies is that quantitative research method should be used to examine the reasons for the slow economic growth in Cameroon. After qualitative method yielded mixed result, quantitative method should be considered for future research. Understanding the reasons for the slow economic growth in Cameroon can enable the country and other developing countries to look for viable sources for economic growth in their countries.

\section{Conclusions}

This research produced a means for the exploration of experiences and opinions of the research participants about the reasons why higher inflow of FDI failed to increase the economic growth in Cameroon. Presented in this research were the implications, recommendations, and conclusions that resulted from the research. The main themes identified were: 1) eco-political; 2) bureaucracy; and 3) corruption. Important implications were discovered with the exploration of the themes. The implications described the contributing factors that influence the poor economic growth in Cameroon despite the higher inflow of FDI. There was evidence of unanimity of views of dysfunctional government due to internal fighting within the President's own party. The participants also expressed consensus opinion on their frustration over widespread and uncontrolled bribery and corruption in all facets of the society, which affects the economic growth. This was consistent with Njong (2008), which found corruption and bribery as major contributions to the poor economic growth in Cameroon. There were also differences of opinion on their missions to investing in Cameroon. There was also significant difference on the determining factors for investing in developing countries such as Cameroon. The differences of opinion may be explained by their focus and the areas of the five participant groups.

The most important finding was on the participants' frustration over widespread and uncontrolled bribery and corruption in all facets of the society, which affects the economic growth. It was proposed that a joint committee be formed to include the government officials and the local business leaders to determine the main causes of the poor economic growth in the country. Most of the participants expressed that elimination of bribery, corruption and bureaucracy would improve the business atmosphere in Cameroon, hence improve its economy. In addition, the research found eco-political factor influencing the economic growth in Cameroon. Most of the research participants pointed out dysfunctional government due to in-house fighting within the President's party over control of powers. On the economic aspects, the study appeals to Cameroon leaders to focus on improving her human capital, financial market and emphasize on export. In addition, it was found that most of the FDI in the country are for the tertiary sector. It was recommended that more exporting FDI are needed in the country to stimulate economic growth (Ajayi, 2009). One of the recommendations was that the government of Cameroon should introduce or execute any existing import duty relief Act. This Act should target imported materials for use in the manufacturing and processing of goods. The Act should reform import duty taxes and be designed to protect domestic producers and promote manufacturing for export market.

Further studies are necessary to explore why the increased inflow of FDI into Cameroon had failed to lead to higher economic growth in the country. Although there are positive relationships between FDI and economic growth in the developing countries such as Cameroon, the findings in this study were inconclusive. The problem of economic growth in Cameroon is a complex issue. It would require more than one source (FDI) or approach to solve. Whereas Forgha (2009) believed in the liberalization of both economic and trade policies; Ajayi (2009) stressed elimination of bureaucracy, corruption and enforcement of existing economic policies to stimulate economic growth in Cameroon.

\section{REFERENCES}

[1] CIA Worldfactbook, "Cameroon Economy," 2010. http://www.theodora.com/wfbcurrent/cameroon/cameroo n_economy.html

[2] D. De Clercq, J. Hessels and van Stel A., "Knowledge Spillovers and New Ventures' Export Orientation," Small Business Economics, Vol. 31, No. 3, 2008, pp. 283-303. doi:10.1007/s11187-008-9132-Z

[3] World Health Organization Cameroon, "Morality and the Burden of Disease," 2008.

http://www.who.int/countries/cmr/en/

[4] CIA Worldfactbook, "Unemployment Rate (\%) 2007 Country Ranks," 2007.

http://www.photius.com/rankings/economy/unemployme 
nt_rate_2007_0.html

[5] A. M. Njong, "Investigating the Effect of Foreign Direct Investment on Export Growth in Cameroon: Final Paper Submitted to UNECA for the 24-25 November, at Addis Ababa, Ethiopia," 2008

http://www.uneca.org/eca programmes/trade and regional ntegrtion/documents/Macro24nov08/FDI\%20and\%Export $\% 20$ Njong\%201pdf

[6] N. G. Forgha, "Foreign Direct Investment and Economic Performance in Cameroon," International Review of Business Research, Vol. 20, No. 5, 2009, pp. 55-69. http://www.bizresearchpapers.com/attachments_2009_01 _14/5.F\%20orgha.pdf

[7] C. R. Darlington and N. Sonny, "Reforming the Legal Environment of Business in Sub-Saharan Countries: Moderating Effects on Foreign Direct Investment," Managerial Law, Vol. 47, 2005, pp. 154-163.

[8] W. C. Kumo, "Foreign Direct Investment in Africa: Trends, Opportunities and Challenges," 2009. http://www.americanchronicle.com/articles/view/87089

[9] S. Tang, E. A. Selvanathan and S. Selvanathan, "Foreign Direct Investment, Domestic Investment, and Economic Growth in China," 2008.

[10] United States Department of States, "Investment Climate Statement-Cameroon Opens to Foreign Investment," 2009.

http://serciciodeestudios.bbva.com/KETD/fbin/mutRevise dChineseOutwardDirectinvestcomparedwithothers format tcm348-200565.pdf

[11] United Nations Conference on Trade and Development, "World Investment Report: Transnational Corporations and the Infrastructure Challenge," New York, 2010.

[12] M. B. Francis, "Growth, Redistribution and Poverty Changes in Cameroon: Ashapley Decomposition Analysis," Journal of African Economies, Vol. 15, No. 4, 2006, pp. 543557, 559-560, 562-563, 565-570.

[13] P. Aghion and P. W. Howitt, "Endogenous Growth Theory," 1987.

http://www.amazon.com/Endogenous-Growth-Theory-Ph ilippe-Aghion/dp/0262011662

[14] E. Ahmed, "Foreign Direct Investment Intensity Effects on TFP Intensity on ASEAN 5 PLUS 2," Journal of Economic Development, Vol. 33, 2008, pp. 155-166.

[15] A. Aghion and P. Howitt, "Model of Growth through Creative Destruction," Econometrica, Vol. 60, No. 2. 1992, pp. 323-335.

http://www.jstor.org/discover/10.2307/2951599?uid=373 9920\&uid $=2$ \&uid $=4 \&$ uid $=3739256 \&$ sid $=211019803357$ 57

[16] Z. Acs, P. Braunerhjelm, D. Audretsch and B. Carlsson, "The Knowledge Spillover Theory of Entrepreneurship," Small Business Economics, Vol. 32, 2009, pp. 15-30.

[17] L. Eden, "Letter from the Editor-in-Chief: FDI Spillovers and Linkages," Journal of International Business Studies, Vol. 40, No. 7, 2009, pp. 1065-1069.

[18] T. Buthe and H. V. Milner, "The Politics of Foreign Di- rect Investment into the Developing Countries: Increasing FDI through International Trade Agreements?" 2008.

http://www.princeton.edu/ hmilner/forthcoming\%20pape rs/ButheMilner_AJPS_PoliticsOfForeignDirectInvestmen tIntoDevelopingCountries.pdf

[19] K. Ofori-Brobbey, L. Ojode and M. Woldie, "Achieving Goal Congruence between the Objectives of Multinational Enterprises (MNEs) and Developing Countries (DCs)," Journal of International Management Studies, Vol. 5, No. 1, 2010, pp. 138-146.

[20] A. Wijeweera, R. Villiano and B. Dollery, "Economic Growth and FDI Inflows: A Stocch Frontier Analysis," The Journal of Developing Areas, Vol. 43, No. 2, 2010, pp. 143-158. doi:10.1353/jda.0.0059

[21] J. H. Dunning and S. M. Lundan, "Multinational Enterprises and the Global Economy," 2nd Edition, Edward Elgar, Cheltenham, 2008.

[22] J. Lee, G. Baimukhamedova and S. Akhmetova, "The Effects of Foreign Direct Investment on Economic Growth of a Developing Country: From Kazakhstan. Allied Academies International Conference," Academy for Economics and Economic Education Proceedings, Vol. 12, No. 2, 2009, pp. 22-27.

[23] I. Jajri, "Foreign Direct Investment and Economic Growth: Cointegration Techniques," Journal of Managerial Economics, Vol. 7, No. 3-4, 2009, pp. 7-18.

[24] T. Kemeny, "Does Foreign Direct Investment Drive Technology Upgrading?” World Development, Vol. 38, No. 11, 2010, p. 1543.

[25] S. L. Ajayi, "Foreign Direct Investment in Sub-Saharan Africa: Origins, Targets, Impacts and Potential. African Economic Research Consortium,” 2008.

http://www.aercafrica.org/documents/books/FDI papers booklength volume.pdf

[26] T. T. Hoang, P. Wiboonchutikula and B. Tubtimtong, "Does Foreign Direct Investment Promote Economic Growth in Vietnam?" ASEAN Economic Bulletin, Vol. 27, No. 3, 2010, p. 295. doi:10.1355/ae27-3d

[27] C. Li, "What Are Emerging Markets? Poster Presentation from the University of Iowa for International Finance and Development," 2007.

http:www.asianfinest.com/forum/index.php?shotopic $=11$ $0462 \&$ view $=$ findpost $\& p=3396485$

[28] K. M. Kasibhatla, D. B. Stewart and M. Khojasteh, "The Role of FDI in High Medium, Low Medium and Low Income Countries during 1970-2005: Empirical Tests and Evidence," The Journal of Business and Economic Studies, Vol. 14, No. 2, 2008, p. 60.

http://search.proquest.com/docview/235803851?accounti $\mathrm{d}=28180$

[29] N. Dutta and S. Roy, "Foreign Direct Investment, Financial Development and Political Risks," The Journal of Developing Areas, Vol. 44, No. 2, 2011, pp. 303-327. doi:10.1353/jda.0.0106

[30] E. Bamou, T. L. Bamou and J. P. Tchanou, "Trade and Investment Policy Reforms in Cameroon: Impact Assessment and Perspectives," African Journal of Economic 
Policy, Vol. 13, No. 1, 2006, pp. 120-150.

www.acp-eu-trade.org/.../Bamou_EN_2006_Yaounde-Un iversity_Ev

[31] MINEFI, "Loi des Finaces 2006: Rapport Economiqueet Financier, Exercices, Yaoundé, Cameroun,” 2006 uneca.org/TRID/.../Macro_24nov08/FDI and Export Njong 1.pdf

[32] United States Department of States, "Investment Climate Statement-Cameroon Opens to Foreign Investment," 2008.

http://serviciodeestudios.bbva.com/KETD/fbin/mult/Revi sedChineseOutwardDirectinvestmewntcomparedwithothers format tcm348-200565.pdf

[33] United States Department of States, "Investment Climate Statement-Cameroon Opens to Foreign Investment," 2009.

http://serviciodeestudios.bbva.com/KETD/fbin/mult/Revi sedChineseOutwardDirectinvestmewntcomparedwithothers format tcm348-200565.pdf

[34] A. Chongvilaivan, "New Frontiers in Free Trade: Globalization's Future and Asia's Rising Role," ASEAN Economic Bulletin, Vol. 27, No. 2010, pp. 234-236.

[35] B. Sharma and J. Abekah, "Foreign Direct Investment and Economic Growth of Africa," Atlantic Economic Journal, Vol. 36, No. 1, 2008, pp. 117-118. doi:10.1007/s11293-007-9103-9

[36] M. Lee and M. Tcha, "The Color of Money: The Effect of Foreign Direct Investment on Economic Growth on Transition Economies," Review of World Economics, Vol. 140, No. 2, 2004, pp. 211-229. doi:10.1007/BF02663646

[37] Z. A. Hailu, "Demand Side Factors Affecting the Inflow of Foreign Direct Investment to African Countries: Does Capital Market Matter?" International Journal of Business and Management, Vol. 5, No. 5, 2010, pp. 104-116. http://search.proquest.com/docview/821544560?accounti $\mathrm{d}=28180$

[38] B. Karabay, "Foreign Direct Investment and Host Country Policies: A Rationale for Using Ownership Restrictions," Journal of Development Economics, Vol. 93, No. 2, 2010, p. 218. doi:10.1016/j.jdeveco.2009.11.003

[39] F. Pusterla and L. Resmini, "Where Do Foreign Firms Locate in Transition Countries? An Empirical Investigation," The Annals of Regional Science, Vol. 41, No. 4, 2007, pp. 835-856. doi:10.1007/s00168-007-0144-4

[40] S. Jigme, "Determinants Affecting Foreign Direct Investment in Bhutan: Perception of Government Officers in BIMST-EC Member Countries," 2006.

www.utcc2.utcc.ac.th/localuser/globalmba/file/Thesis Topic

[41] J. Jones and C. Wren, "Foreign Direct Investment and the Regional Economy," Athenaeum Press, Palgrave, 2006.

[42] K. E. Meyer and L. Sinai, "The Impact of FDI: A MetaAnalysis. Denmark, Copenhagen Business School," 2006. http://www.klausmeyer.co.uk/publications/2005_meyer_ EMF_Templeton.pdf

[43] B. David and D. Nigel, "Industrial Policy, FDI and Em- ployment: Still Missing a Strategy," Journal of Industry, Competition and Trade, Vol. 7, No. 3-4, 2007, pp. 189211. doi:10.1007/s10842-006-7185-8

[44] S. Jigme, "Determinants Affecting Foreign Direct Investment in Bhutan: Perception of Government Officers in BIMST-EC Member Countries," 2006. www.utcc2.utcc.ac.th/localuser/globalmba/file/Thesis Topic

[45] S. Reiter and H. Steensma, "Human Development and Foreign Direct Investment in Developing Countries: The Influence of FDI Policy and Corruption," World Development, Vol. 38, No. 12, 2010, p. 1678.

[46] T. T. Hoang, P. Wiboonchutikula and B. Tubtimtong, "Does Foreign Direct Investment Promote Economic Growth in Vietnam?" ASEAN Economic Bulletin, Vol. 27, No. 3, 2010, p. 295. doi:10.1355/ae27-3d

[47] L. K. Jenkins, "Aging in a Confined Place: An Exploration of Elder Inmate Health and Healthcare," Doctoral Dissertation, 2009.

[48] N. Karim and S. Ahmad, "Foreign Direct Investment: Key to Poverty Reduction in Malaysia," Journal of Applied Economics, Vol. 8, No. 5-6, 2009, pp. 55-64.

[49] R. Mora and R. Forte, "The Effects of Foreign Direct Investment on the Host Country Economic Growth-Theory and Empirical Evidence," 2009. www.etsg.org/ETSG2009/papers/forte.pdf

[50] H. Varamini and A. Vu, "Foreign Direct Investment in Vietnam and Its Impact on Economic Growth," International Journal of Business Research, Vol. 7, No. 6, 2007, pp. 132-139. www.etsg.org/ETSG2009/papers/forte.pdf

[51] H. Krifa-Schneider and I. Matei, "Business Climate, Political Risk and FDI in Developing Countries: Evidence from Panel Data," International Journal of Economics and Finance, Vol. 2, No. 5, 2010, pp. 54-65.

[52] N. Loayza and C. Raddatz, "The Composition of Growth Matters for Poverty Alleviation," Journal of Development Economics, Vol. 93, No. 1, 2010, p. 137.

[53] M. Majeed and E. Ahmad, "An Analysis of Host Country Characteristics That Determine FDI in Developing Countries: Recent Panel Data Evidence," The Lahore Journal of Economics, Vol. 14, No. 2, 2009, pp. 71-96.

[54] N. Karim and S. Ahmad, "Foreign Direct Investment: Key to Poverty Reduction in Malaysia," Journal of Applied Economics, Vol. 8, No. 5-6, 2009, pp. 55-64.

[55] A. Johnson, "Rethinking Bilateral Investment Treaties in Sub-Saharan Africa," Emory Law Journal, Vol. 59, No. 4, 2010, pp. 919-967.

[56] A. E. Alesina and R. Perotti, "The Political Economy of Growth: A Critical Survey of Literature," World Bank Review, Vol. 11, No. 5, 2008, pp. 351-360. www.ecineq.org/ecineq_ba/papers/rodriguez.pdf

[57] A. Al-Sadig, "The Effects of Corruption on FDI Inflows," Cato Journal, Vol. 29, 2009, pp. 267-294.

[58] A. J. Onwuegbuzie and N. L. Leech, "A Call for Qualitative Power Analyses," Quality \& Quantity, Vol. 41, No. 1, 


\section{7, pp. 105-121. doi:10.1007/s11135-005-1098-1}

[59] S. Guerin and S. Manzocchi, "Political Regime and FDI from Advanced to Emerging Countries," Review of World Economics, Vol. 145, No. 1, 2009, pp. 75-91. doi:10.1007/s10290-009-0004-7

[60] L. Ndikumana and S. Verick, "The Linkages between FDI and Domestic Investments: Unraveling the Developmental Impact of Foreign Direct Investment in Sub-Saharan Africa," 2008 ftp.iza.org/dp3296.pdf

[61] D. Haglund, "Regulating FDI in Weak African States: A Case Study of Chinese Copper Mining in Zambia," The Journal of Modern African Studies, Vol. 46, No. 4, 2008, pp. 547-575. doi:10.1017/S0022278X08003480

[62] K. P. Sauvant, W. A. Maschek and G. McAllister, "Foreign Direct Investment by Emerging Market Multinational Crisis and Recession and Challenges Ahead. Globalforum on International Investment," 2009. http://www.oecd.org/dataoecd/9/2/44246197.pdf

[63] N. Uttama and N. Peridy, "Foreign Direct Investment and Productivity Spillovers: The Experience of ASEAN Countries," Journal of Economic Integration, Vol. 25, No. 2, 2010, pp. 298-323. doi:10.11130/jei.2010.25.2.298

[64] P. Amin, "Foreign Direct Investment: A Comparative Analysis of Canada and India," 2007. http://www.indianmba.com/FacultyColumn/Fc823/Fc823. html

[65] A. Amighini, R. Rabellotti and M. Sanfilippo, "Outward
FDI from Developing Country MNEs as a Channel for Technological Catch-Up," Seoul Journal of Economics, Vol. 23, 2010, pp. 239-261.

[66] N. Loayza and C. Raddatz, "The Composition of Growth Matters for Poverty Alleviation," Journal of Development Economics, Vol. 93, No. 1, 2010, p. 137.

[67] United Nations Conference on Trade and Development, "World Investment Report: Transnational Corporations and the Infrastructure Challenge," New York, 2009.

[68] R. Yin, "Case Study Research: Design and Methods," 4th Edition, Sage, London, 2009.

[69] M. Q. Patton, "Qualitative Research \& Evaluative Methods," Sage, London, 2004.

[70] D. Haglund, "Regulating FDI in Weak African States: A Case Study of Chinese Copper Mining in Zambia," The Journal of Modern African Studies, Vol. 46, No. 4, 2008, pp. 547-575. doi:10.1017/S0022278X08003480

[71] G. Rochon, D. Niyogi, S. Fall, J. Quansah, L. Biehl and B. Araya, "Best Management Practices for Corporate, Academic and Governmental Transfer of Sustainable Technologies to Developing Countries," Clean Technologies and Environmental Policy, Vol. 12, No. 1, 2010, pp. 19-30. doi:10.1007/s10098-009-0218-3

[72] QSR International, "Software for Qualitative ResearchFrom Academic and Social Science to Market Research," 2007. http://www.qsrinternational.com/ 